\title{
Analisis Variasi Diurnal Curah Hujan di Sumatera Barat Menggunakan Data Rain Gauge dan IMERG
}

\author{
Krisna Suryanti ${ }^{1)}$, Dian Fitriyani ${ }^{1}$, Robi Muharsyah ${ }^{2}$, Marzuki $^{*}{ }^{*}$ \\ ${ }^{1}$ Jurusan Fisika, Fakultas Matematika dan Ilmu Pengetahuan Alam Universitas Andalas, Indonesia \\ Limau Manis, Padang, Sumatera Barat 25163 \\ ${ }^{2}$ Badan Meteorologi, Klimatologi, dan Geofisika (BMKG), Jl. Angkasa 1 No. 2, Kemayoran, Jakarta Pusat \\ *Email : marzuki@sci.unand.ac.id
}

(Diterima 5 Januari 2020; Disetujui 24 Oktober 2020; Dipublikasikan 29 Desember 2020)

\begin{abstract}
Abstrak
Variasi diurnal adalah salah satu komponen utama variasi atmosfer di kawasan tropis yang menimbulkan dampak terhadap siklus hidrologi dan bidang terkait. Sebagai interaksi antara daratan dan lautan sekitarnya, fenomena ini dipengaruhi oleh kondisi topografi. Penelitian ini bertujuan untuk menganalisis variasi diurnal dari akumulasi, frekuensi dan intensitas curah hujan dalam kaitannya dengan topografi di Sumatera Barat menggunakan data rain gauge dari 17 stasiun selama 2014-2019. Pola diurnal dan semidiurnal curah hujan dimodelkan melalui metode dekomposisi harmonik menggunakan discrete Fourier transform (DFT). Secara umum, akumulasi dan frekuensi curah hujan daerah pesisir pantai dan dataran tinggi, lebih besar daripada daerah dataran rendah. Namun sebaliknya, intensitas curah hujan lebih besar di dataran rendah daripada wilayah pesisir pantai dan dataran tinggi. Secara umum puncak intensitas curah hujan terjadi pada pukul 15.00-16.00 WIB pada daerah pesisir pantai dan pada pukul 17.00-18.00 WIB di dataran rendah. Hujan memiliki frekuensi kemunculan tertinggi pada pukul 16.00-18.00 WIB di sebagian besar daerah pesisir pantai dan pada pukul 19.00-21.00 WIB di dataran rendah. Puncak akumulasi hujan terjadi pada pukul 16.00-19.00 WIB di sebagian besar daerah pesisir pantai dan pada pukul 20.00-22.00 WIB di dataran rendah. Puncak curah hujan pada pagi hari juga ditemukan di pulaupulau kecil pada kawasan Sumatera Barat. Selain puncak dominan pada sore hari, beberapa lokasi memiliki puncak kedua yang intensitasnya lebih rendah. Puncak dari akumulasi, frekuensi dan intensitas curah hujan dari rain gauge konsisten dengan data integrated multi-satellite retrievals for GPM (IMERG) tetapi puncak curah hujan dari data IMERG satu jam lebih lambat daripada data rain gauge, sebagaimana pernah ditemukan oleh peneliti sebelumnya. Akumulasi, frekuensi dan intensitas curah hujan diurnal sesuai dengan pola distribusi variasi diurnal temperatur dan kelembaban relatif.
\end{abstract}

Kata kunci: curah hujan, IMERG, siklus diurnal, Sumatera Barat

\section{Latar Belakang}

Pulau Sumatera merupakan salah satu kawasan di Indonesia yang mempengaruhi sirkulasi global. Letak Sumatera yang hampir tegak lurus garis ekuator serta deretan Pegunungan Bukit Barisan dengan ketinggian hingga 3.000 meter di atas permukaan laut menyebabkan Sumatera menjadi penghalang bagi aliran atmosfir dan pergerakan awan dari Samudra Hindia [1,2]. Kondisi ini mengakibatkan curah hujan banyak terjadi di sepanjang wilayah pesisir barat Sumatera, yaitu Sumatera Barat [3]. Daerah dengan karakteristik topografi yang berbeda dapat mempengaruhi suhu udara yang berhubungan dengan tingkat penguapan untuk pembentukan awan yang menghasilkan hujan [4].

Siklus diurnal menjadi salah satu penyebab terjadinya variasi konveksi yang paling signifikan di wilayah tropis dan sangat komplek di Sumatera [5], hal ini berkaitan dengan adanya barisan pegunungan yang menyebabkan proses pembentukan awan dan hujan di Sumatera dipengaruhi oleh kondisi alam tersebut. Proses terjadinya siklus diurnal berkaitan dengan pola angin darat dan angin laut yang berdampak pada perbedaan karakteristik hujan yang terjadi di daerah yang berbeda kondisi topografinya. Pemahaman mengenai siklus diurnal penting untuk dipelajari karena dapat mempengaruhi iklim dalam skala global [6] dan membentuk keragaman curah hujan lokal [7].

Penelitian tentang variasi diurnal curah hujan di pulau Sumatra, khususnya di Sumatera Barat telah dilakukan oleh beberapa peneliti $[5,6,8,9]$. Misalnya, $\mathrm{Wu}$ et al. [5] dan Mori et al. [6] menyelidiki pola variasi diurnal curah hujan di Pulau Sumatra menggunakan data satelit tropical rainfall measuring mission (TRMM) dan radiosonde. 
Penelitian ini menunjukan di daratan hujan lebih banyak terjadi pada malam hari (19.00 WIB) daripada pagi hari (07.00 WIB) [8]. Penelitian serupa dilakukan oleh Love et al., [9] di Benua Maritim, hujan pagi banyak ditemukan di lautan pada pukul 09.00 WIB dan di daratan pada pukul 21.00 WIB. Penelitian-penelitian tersebut menunjukan bahwa perbedaan waktu pola curah hujan disebabkan oleh angin darat dan angin laut [6] yang mengalami migrasi dari lautan menuju daratan dengan kawasan daratan memiliki puncak curah hujan terjadi pada sore hari.

Penelitian di atas sebagian besar mengandalkan data TRMM dan pengamatan insitu yang terbatas. Pada penelitian ini, akan dilakukan analisis variabilitas curah hujan diurnal di Sumatera Barat menggunakan data rain gauge dari Badan Meteorologi, Klimatologi dan Geofisika (BMKG) dan data integrated multi-satellite retrievals for GPM (IMERG). Penggunaan data rain gauge BMKG untuk pengamatan variasi diurnal curah hujan di Sumatera Barat belum pernah dilakukan dan penggunaan data IMERG karena data IMERG dapat mendeteksi curah hujan yang cukup akurat khususnya untuk curah hujan dengan intensitas lebih dari $15 \mathrm{~mm} / \mathrm{h}$ pada penelitian sebelumnya di wilayah Surabaya [10]. Penelitian ini diharapkan dapat meningkatkan pemahaman kita mengenai karakteristik curah hujan diurnal di Sumatera Barat pada topografi yang berbeda yang berperan penting dalam pembentukan pola curah hujan lokal dan regional $[5,6]$.

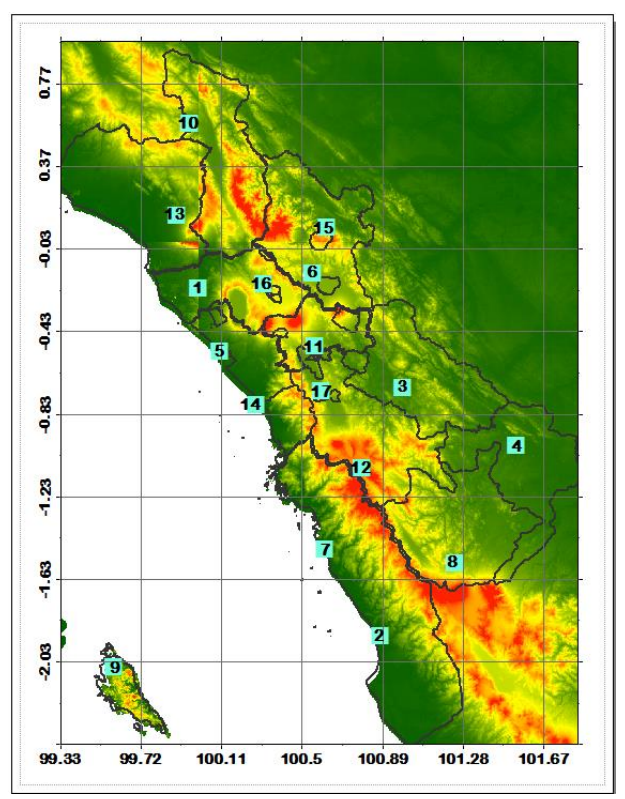

Gambar 1. Lokasi stasiun rain gauge di Sumatera Barat

\section{Metodologi}

\section{A. Data Penelitian}

Penelitian ini menggunakan data rain gauge untuk mengetahui nilai frekuensi, intensitas dan akumulasi puncak curah hujan dari 17 stasiun BMKG yang terdapat di Sumatera Barat (Gambar 1). BMKG mengoperasikan tiga tipe instrumen, yaitu automatic rain gauge (ARG), automatic weather station (AWS), dan automatic agroclimate weather system (AAWS). Data ARG, AWS, dan AAWS memiliki resolusi waktu 10 menit. Informasi stasiun dan periode pengamatan dapat dilihat pada Tabel 1. Data yang digunakan dari stasiun ARG adalah data curah hujan, sedangkan dari data AWS dan AAWS digunakan data curah hujan, temperatur, dan kelembaban relatif.

Tabel1.Informasi stasiun pengamatan

\begin{tabular}{|c|c|c|}
\hline No & Identitas Stasiun & $\begin{array}{l}\text { Periode } \\
\text { (tahun) }\end{array}$ \\
\hline 1. & ARG Ampek Nagari & $2015-2019$ \\
\hline 2. & ARG Linggosari Baganti & $2015-2019$ \\
\hline 3. & ARG Sijunjung & $2015-2019$ \\
\hline 4. & ARG Sungai Dareh & $2015-2019$ \\
\hline 5. & ARG Sungai Limau & $2017-2019$ \\
\hline 6. & ARG Guguak & $2017-2019$ \\
\hline 7. & ARG Batang Kapas & $2017-2019$ \\
\hline 8. & ARG Solok Selatan & $2017-2019$ \\
\hline 9. & ARG Sipora Jaya & $2017-2019$ \\
\hline 10. & ARG Rao Pasaman & $2014-2019$ \\
\hline 11 & ARG Tanah Datar & $2014-2019$ \\
\hline 12. & AWS Alahan Panjang & $2015-2019$ \\
\hline 13. & AWS Pasaman Barat & $2017-2019$ \\
\hline 14. & AWS Stamet Padang & $2016-2018$ \\
\hline 15. & AAWS Harau & $2014-2018$ \\
\hline 16. & $\begin{array}{l}\text { AAWS Bukit } \\
\text { Kototabang }\end{array}$ & $2014-2019$ \\
\hline 17. & AAWS Balitbu Sumani & $2015-2019$ \\
\hline
\end{tabular}

Data lain yang digunakan yaitu data curah hujan dari satelit GPM berupa data IMERG selama tahun 2015-2017 untuk seluruh Sumatera Barat. Data IMERG memiliki resolusi spasial $0.1^{\circ}$ dan resolusi waktu 30 menit. IMERG menghasilkan hasil yang lebih baik untuk mendeteksi curah hujan peristiwa atas dasar probability of detection (POD), 
critical success index (CSI) dan false alarm ratio (FAR) di daerah-daerah dengan curah hujan stratiform dan orografis, seperti Teheran dan Kermanshah (Iran), dibandingkan dengan satelit lain. IMERG lebih unggul dari produk lain di semua wilayah studi dan bisa digunakan di masa depan untuk model meteorologi dan hidrologi [11]. Selain itu, perkiraan curah hujan di Surabaya menggunakan data IMERG memiliki korelasi yang sangat baik untuk memperkirakan akumulasi curah hujan bulanan [10].

\section{B. Penentuan Distribusi Curah Hujan Diurnal.}

Presentase frekuensi, intensitas dan akumulasi hujan dihitung untuk setiap kejadian hujan dari data hujan rain gauge dan IMERG. Definisi dari setiap parameter tersebut adalah sebagai berikut [12]. Presentase frekuensi hujan atau precipitation frequency (PF) adalah jumlah total data yang ada hujannya dibagi total data keseluruhan. Akumulasi hujan atau precipitation amount (PA) adalah jumlah total curah hujan dibagi durasi data dalam jam. Intensitas hujan atau precipitation intensity (PI) merupakan jumlah total curah hujan dibagi durasi hujan dalam jam.

Temporal resolution dari IMERG data adalah 30 menit. Baik IMERG dan rain gauge data, hujan diasumsikan terjadi jika intensitas curah hujan $>0$. Hujan dianggap satu kejadian (rain event) yang sama jika hujan tersebut terjadi dengan interval kurang dari satu jam [13]. Untuk mengamati pola diurnal dan semidiurnal dari tiga parameter di atas maka digunakan dekomposisi harmonik melalui discrete Fourier transform (DFT), dengan menggunakan transformasi Fourier pola osilasi akan terlihat sebagai puncak (peak) pada frekuensi tertentu. Puncak energi spektral menunjukkan adanya keberadaan pola osilasi dominan secara periodik [14]. Variasi diurnal dari data rain gauge dibandingkan dengan data IMERG berdasarkan nilai ketiga tipe instrument dan puncak jam hujan pada masing-masing stasiun. Untuk melihat mekanisme yang mempengaruhi variasi diurnal, digunakan data temperatur dan kelembaban relatif yang diplot dalam deret waktu.

\section{Hasil dan Pembahasan}

\section{A. Pola Distribusi Intensitas, Frekuensi dan Akumulasi Hujan Diurnal}

Gambar 2 menunjukkan variasi diurnal dari nilai PI pada 17 stasiun rain gauge di Sumatera
Barat. Sekitar 61\% stasiun menunjukkan puncak maksimum pada pukul 16.00-17.00 WIB, 29\% puncak PI teramati pada pukul 15.00 WIB dan 17.00 WIB, $35 \%$ pada pukul 16.00 WIB dan satu stasiun yaitu Stamet Padang memiliki puncak PI pada pukul 18.00 WIB. Sekitar $88 \%$ stasiun memiliki nilai PI $>7 \mathrm{~mm} / \mathrm{h}$ pada pukul $14.00-17.00$ WIB. Nilai DFT PI maksimum berada pada stasiun Pasaman Barat yaitu 13,66 mm/h dan nilai DFT PI maksimum terkecil berada pada stasiun Balitbu Sumani yaitu 4,6 mm/h. Pola nilai DFT PI stasiun Balitbu Sumani mempunyai hubungan dengan durasi hujan. Durasi hujan pada stasiun dengan nilai DFT PI maksimum jauh lebih pendek dibandingkan stasiun dengan nilai DFT PI maksimum terkecil. Hal ini konsisten dengan pola curah hujan di Sumatera Barat yang dilaporkan oleh peneliti sebelumnya, bahwa hujan dengan intensitas tinggi terjadi dalam durasi yang pendek dan wilayah cakupan yang kecil [15].

Selain puncak utama (DFT maksimum), juga teramati puncak kedua pada beberapa stasiun. Hal ini semakin terlihat jelas dari hasil DFT, yaitu terdapat dua kali puncak dengan tinggi yang hampir sama atau lebih rendah. Stasiun dengan dua puncak DFT PI adalah stasiun Sipora Jaya (no. 9 pada Gambar 1), Batang Kapas (no. 7), Pasaman Barat (no. 13), dan Linggosari Baganti (no. 2). Puncak ke-2 dari nilai DFT PI teramati pada dini hari (03.00-04.00 WIB) mirip dengan puncak curah hujan di kawasan pantai yang dilaporkan oleh Mori et al. [6]. Jika kita lihat dari distribusi stasiun dengan dua puncak DFT PI, stasiun-stasiun ini posisinya dekat dengan pantai. Pada penelitian sebelumnya menemukan bahwa variasi semidiurnal (puncak kedua) di Cina tenggara dipengaruhi oleh pemanasan diferensial daratan dan lautan [16]. Dengan demikian, puncak ke-2 dari PI merupakan akibat dari migrasi hujan dari daratan Sumatera menuju ke lautan.

Gambar 3. menunjukan distribusi jumlah akumulasi curah hujan diurnal (PA). Sekitar 83\% nilai PA menunjukan nilai kecil dari $0,5 \mathrm{~mm} / \mathrm{h}$. Terdapat tiga stasiun dengan $\mathrm{PA}>0,5 \mathrm{~mm} / \mathrm{h}$, yaitu stasiun Linggosari Baganti $(0,6 \mathrm{~mm} / \mathrm{h})$, stasiun Batang Kapas $(0,57 \mathrm{~mm} / \mathrm{h})$ dan stasiun Pasaman Barat $(1,10) \mathrm{mm} / \mathrm{h}$. Nilai PA terkecil berada pada stasiun Balitbu Sumani yaitu 1,2 mm/h. Hal ini juga konsisten dengan nilai intensitas dimana stasiun Balitbu Sumani memiliki nilai intensitas curah hujan yang relative kecil (Gambar 2q). Dari nilai 

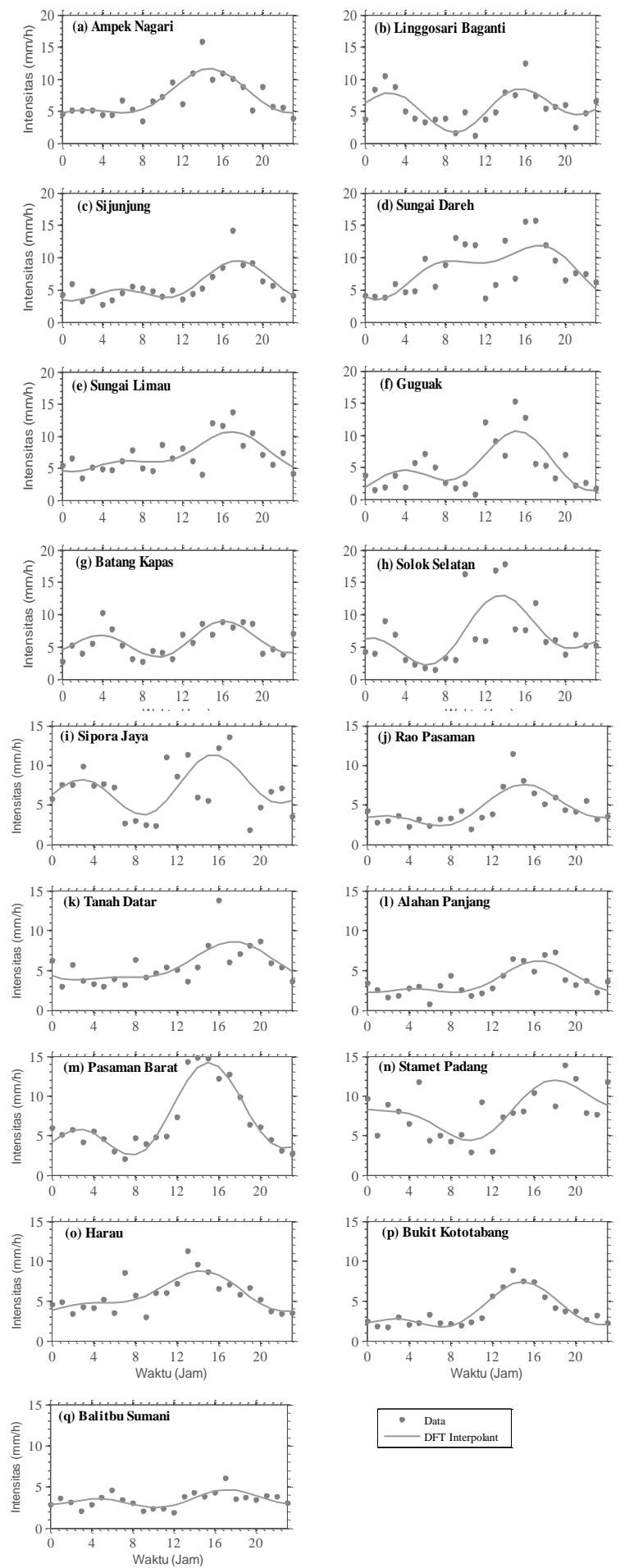

Gambar 3. Variasi diurnal data PI dan DFT.

DFT, juga teramati puncak kedua dari nilai PA yaitu pada stasiun Linggosari Baganti, Sipora Jaya dan Pasaman Barat. Batang Kapas yang memiliki puncak kedua PI tidak menunjukkan puncak kedua PA yang jelas.

Perbedaan nilai PA pada stasiun pengamatan memiliki hubungan dengan kondisi topografi dan jarak stasiun ke pantai. Sekitar $61 \%$ stasiun dengan
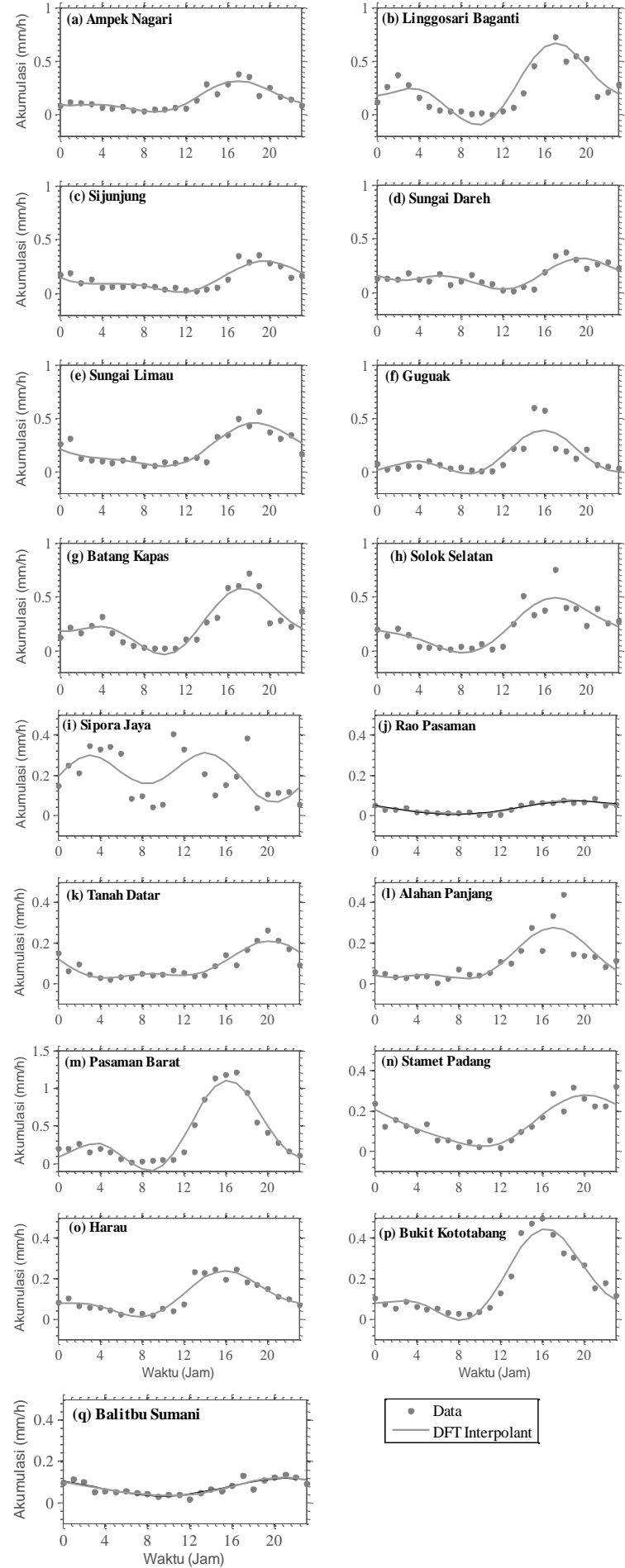

\begin{tabular}{l}
- Data \\
- DFT Interpolant \\
\hline
\end{tabular}

Gambar 2. Variasi diurnal data PA dan DFT.

nilai rata-rata $\mathrm{PA}>0.3 \mathrm{~mm} / \mathrm{h}$ berada pada daerah pesisir dan dataran tinggi.

Gambar 4 menunjukan distribusi frekuensi curah hujan rata-rata (PF). Sebagian besar puncak DFT PF maksimum terjadi pada malam hari yang menandakan bahwa hujan paling sering terjadi pada malam hari. Sebesar 29\% DFT PF maksimum teramati pada pukul 18:00 WIB, 17\% pada pukul 

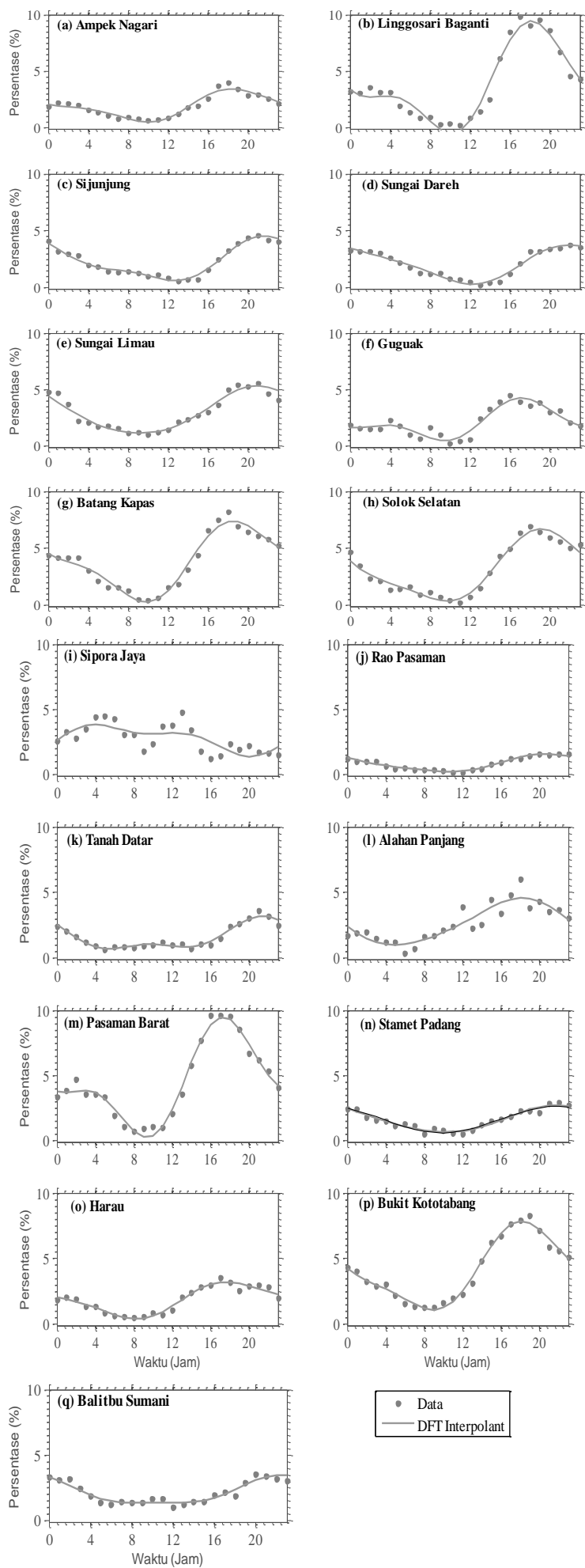

- Data
- DFT Interpolant

Gambar 5. Variasi diurnal data PF dan DFT.

16.00-17.00 WIB, dan sebesar $41 \%$ teramati diatas pukul 21.00 WIB. Satu stasiun yaitu Sipora Jaya yang berada di lautan memiliki DFT PF maksimum pada pukul 04.00 WIB (dini hari). Sekitar $83 \%$ nilai DFT PF menunjukan nilai maksimum $>2,5 \%$. Terdapat satu stasiun dengan nilai DFT PA maksimum terkecil dari 2,5\%, yaitu stasiun Rao Pasaman (1,58\%). Nilai DFT PF maksimum berada
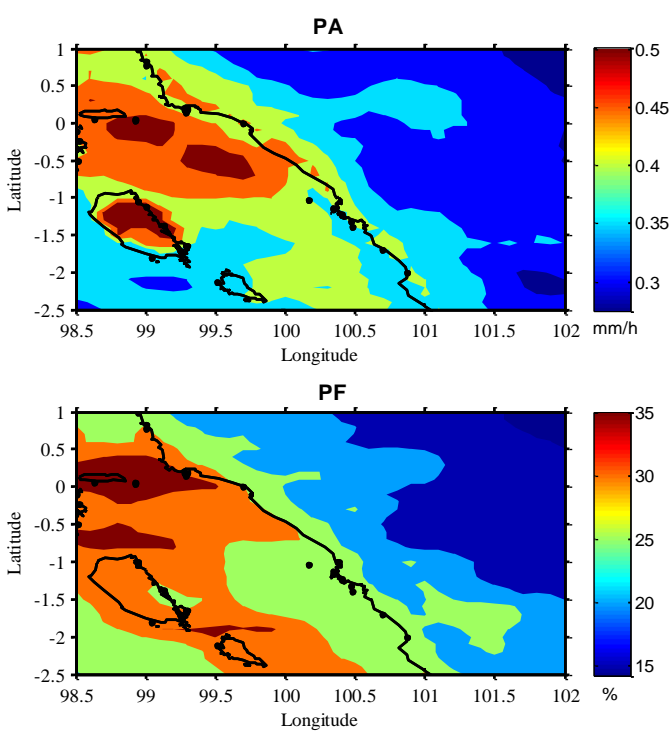

$\mathbf{P}$

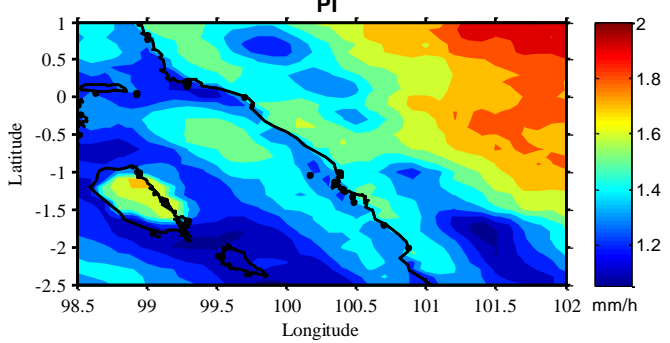

Gambar 4. Nilai rata-rata PA, PF,dan PI dari satelit GPM (IMERG).

pada stasiun Pasaman Barat $(9,48 \%)$. Berbeda dengan DFT PA dan PI, PF tidak memperlihatkan puncak kedua yang jelas. Stasiun Linggosari Baganti, Sipora Jaya dan Pasaman Barat yang memiliki dua puncak DFT PA dan PI, tidak menunjukkan adanya puncak kedua untuk nilai DFT PF.

Perbedaan nilai DFT PF pada stasiun pengamatan memiliki hubungan dengan kondisi topografi. Sekitar 67\% stasiun dengan nilai DFT PF maksimum $>3 \%$ berlokasi pada daerah pesisir dan dataran tinggi. Hal ini konsisten dengan penelitian sebelumnya bahwa aliran angin lembah (upslope) dominan terjadi di sisi barat Bukit Barisan [17]. Secara keseluruhan nilai DFT PA dan PF lebih besar pada daerah pesisir pantai dan dataran tinggi (Bukit Barisan) daripada dataran rendah (jauh dari pantai). Namun sebaliknya, nilai PI ditemukan lebih tinggi pada dataran rendah (jauh dari pantai) daripada daerah pesisir dan dataran tinggi.

Gambar 5 menunjukan nilai rata-rata PA, PF dan PI dari satelit GPM (data IMERG). Hasil yang ditemukan mempunyai pola yang sama dengan data permukaan (rain gauge). Nilai PA lebih besar di sekitar pesisir pantai $(>0,4 \mathrm{~mm} / \mathrm{h})$ dan lautan $(>0,45)$ daripada daratan $(<0,3 \mathrm{~mm} / \mathrm{h})$. Nilai $\mathrm{PF}$ juga ditemukan mempunyai pola yang serupa. Nilai 
PF lebih besar ditemukan di lautan (>30\%), kemudian menyebar ke pesisir pantai ( $>25 \%)$ serta dataran tinggi (>20\%). Namun nilai PI menunjukan kondisi sebaliknya dimana nilai PI lebih besar di dataran rendah $(>1,6 \mathrm{~mm} / \mathrm{h})$ daripada dataran tinggi dan pesisir $(<1,6 \mathrm{~mm} / \mathrm{h})$ serta ditemukan lebih rendah di lautan $(<1,4 \mathrm{~mm} / \mathrm{h})$. Dengan demikian, di daerah pantai akumulasi curah hujan tinggi namun memiliki intensitas yang rendah, sedangkan daerah daratan Sumatera Barat memiliki frekuensi dan akumulasi yang rendah namun intensitas hujan yang besar. Hal ini konsisten dengan penelitian sebelumnya [16]. Pola puncak diurnal PA, PF dan PI pada data satelit juga menggambarkan hal serupa (Gambar 6). Puncak PA, PI dan PF di daratan Sumatera Barat dominan terjadi pada sore dan malam hari sebagaimana juga teramati pada data rain gauge.

Puncak diurnal PA dari data IMERG satu jam lebih lambat dari data rain gauge. Puncak PA di daerah pesisir pantai teramati pada pukul 18.0020.00 WIB, dan di dataran rendah pada pukul 20.00 WIB. Puncak diurnal PF di pesisir pantai dan dataran rendah ditemukan pada pukul 17.00-19.00 WIB, sedangkan pada dataran tinggi pada pukul 20.00-21.00 WIB. Puncak diurnal PI di pesisir
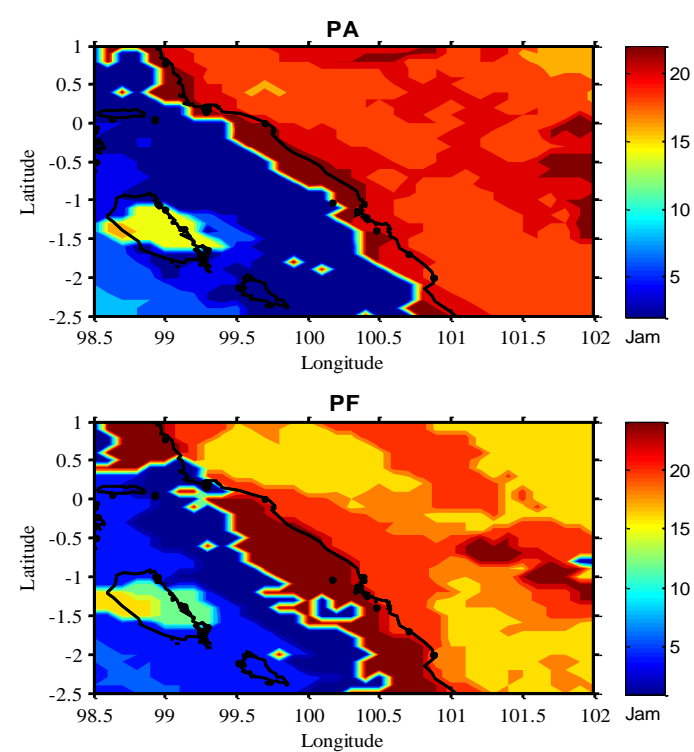

PI

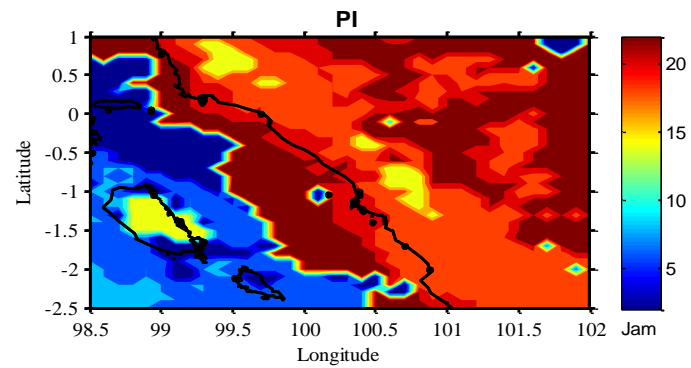

Gambar 6. Puncak PA, PF, P I dari satelit GPM. pantai dan dataran tinggi ditemukan pada pukul 19.00-20.00 WIB dan di dataran rendah pada pukul 22.00 WIB. Perbedaan ini kemungkinan disebabkan oleh perbedaan resolusi temporal data pegamatan antara IMERG dan rain gauge. Selain itu, perbedaan ini juga disebabkan oleh sensitivitas sensor yang terlibat dalam pembentukan data IMERG. Sensor IMERG menunjukkan kinerja yang lebih baik (lebih sensitif) dalam mendeteksi curah hujan konvektif yang kemunculannya berbeda satu jam dari hujan yang lain terutama hujan statiform [18]. Keterlambatan puncak diurnal ini juga pernah dilaporkan oleh peneliti sebelumnya bahwa terjadi keterlambatan dalam fase diurnal data IMERG dengan rain gauge sekitar +0,59 jam di Benua Maritim [20] dan 1-2 jam di Cina [21].

\section{B. Pola Distribusi Temperatur dan Kelemba- ban Relatif}

Terdapat 6 stasiun yang menyediakan data temperatur dan kelembaban permukaan (Gambar 7). Untuk jam yang sama, temperatur minimum, maksimum dan temperatur rata-rata hampir sama. Pada siang hari rata-rata temperatur permukaan lebih tinggi dari periode lainnya. Kenaikan temperatur dimulai pada pukul 09.00 WIB dan mencapai puncaknya pada pukul 12.00-13.00 WIB. Hal berbeda teramati untuk kelembaban relatif yang menunjukkan kelembaban tertinggi pada dini hari (04.00-07.00 WIB) dan malam hari (20.0023.00 WIB). Kelembaban permukaan yang rendah
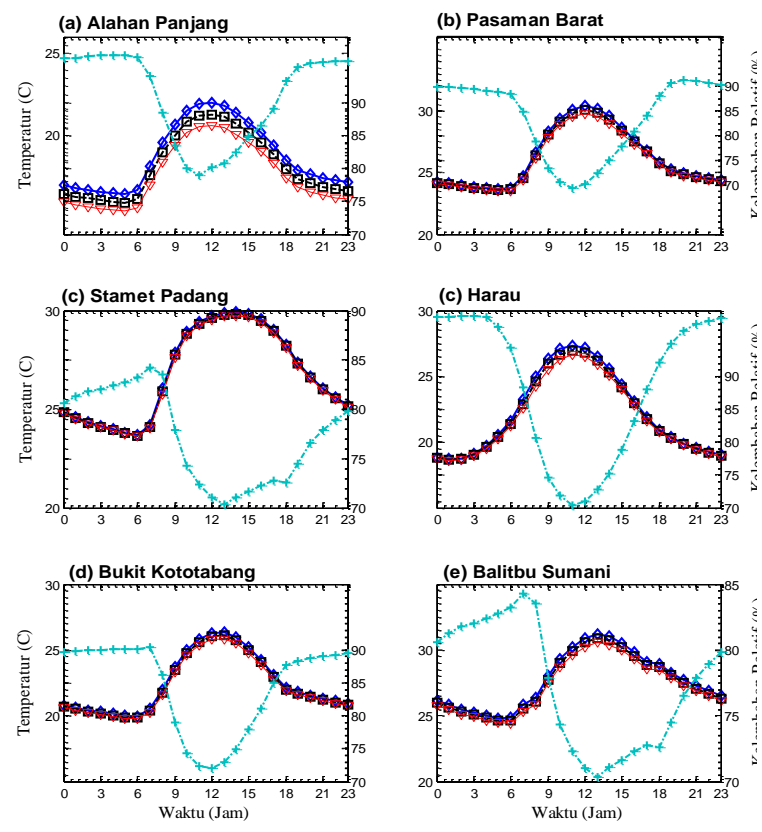

$\rightarrow \multimap$ Temp. max. --E--- Temp. rata-rata $\square$ Temp. min. --+-- Kelembaban Relatif

Gambar 7. Variasi diurnal temperatur dan kelembaban relatif. 
di permukaan pada saat temperatur udara tinggi menandakan tingginya tingkat evaporasi. Hal ini mendorong pertumbuhan awan yang kemudian menghasilkan hujan.

Dari keenam stasiun ini 5 diantaranya terletak pada daerah dataran tinggi, dan satu berada di pesisir pantai. Stasiun Stamet Padang berada di pesisir pantai dan menunjukkan bahwa konveksi yang terjadi di pesisir pantai mempunyai durasi yang lebih lama dibandingkan daerah dataran tinggi. Pemanasan permukaan terjadi lebih cepat dan puncaknya terjadi pada pukul 14.00 WIB, berbeda 1-3 jam dari stasiun lain yang berada di dataran tinggi. Tingkat kelembaban pada dataran tinggi lebih tinggi dibandingkan daerah pesisir pantai. Perbedaan variasi diurnal temperatur dan kelembaban ini mempengaruhi variasi diurnal curah hujan terutama frekuensi hujan (Gambar 4n). Pola diurnal frekuensi hujan di Stamet Padang tidak begitu jelas.

\section{Kesimpulan}

Secara umum, hasil penelitian ini menguatkan penelitian sebelumnya bahwa variasi diurnal curah hujan dipengaruhi oleh kondisi topografi di Sumatera Barat. Hujan paling sering terjadi pada pukul 16.00-18.00 WIB di sebagian besar daerah pesisir pantai dan pada pukul 19.00-21.00 WIB di dataran rendah. Hal ini konsisten dengan puncak akumulasi curah hujan yang terjadi pada pukul 16.00-19.00 WIB di sebagian besar daerah pesisir pantai dan pada pukul 20.00-22.00 WIB di dataran rendah. Namun, daerah dengan akumulasi curah hujan yang tinggi memiliki intensitas curah hujan yang rendah dan durasi hujan yang lebih lama. Puncak dominan yang terjadi pada siang hari ini konsisten dengan pola temperatur dan kelembaban udara permukaan. Hal ini menandakan bahwa hujan di Sumatera Barat dipengaruhi secara kuat oleh sirkulasi angin darat dan angin laut, sebagai bagian interaksi daratan dan lautan sekitar. Selain puncak dominan pada siang hari, beberapa stasiun terutama yang dekat pantai memiliki puncak curah hujan pada dini hari. Hal ini merupakan imbas dari pergerakan hujan dari daratan ke lautan. Pola diurnal dari rain gauge mirip dengan yang didapatkan dari data IMERG tetapi puncak curah hujan dari data IMERG satu jam lebih lambat daripada data rain gauge.

\section{UcapanTerimaKasih}

Penelitian ini didukung oleh Hibah Riset Dasar 2019 dari Kementerian Riset, Teknologi, dan Pendidikan Tinggi (Nomor kontrak: T/8/ UN.16.17 /PT.01.03/PD-Kebencanaan/2019). Penulis mengucapkan terima kasih kepada Badan Meteorologi, Klimatologi dan Geofisika (BMKG) yang telah menyediakan data untuk tujuan penelitian.

\section{Daftar Pustaka}

[1] Zhang, C. dan J. Ling., Barrier Effect of the IndoPacific Maritime Continent on the MJO: Perspectives from Tracking MJO Precipitation, Journal of Climate, 30, pp. 3439-3459, 2017.

[2] Hermawan, E., Analisis Perilaku Curah Hujan di Atas Kototabang saat Bulan Basah dan Bulan Kering, in Prosiding Seminar Nasional Penelitian, Pendidikan,dan Penerapan MIPA, Kismiyantini, et al. (eds), pp. F-415-424, 2009.

[3] Marpaung, S., Satiadi, D dan Harjana, T., Analisis kejadian curah hujan ekstrem di pulau sumatera berbasis data satelit TRMM dan data permukaan, Jurnal sains dirgantara, 9(2), pp.127-138, 2012.

[4] Alfuadi, N. dan Prayuda, S.S., The Role of Atmospheric Science and Technology," in the Preservation of the Earth and Environment, SNSA conference Proceedings 308, E. Hermawan et al (eds), pp.FB56-FB64, 2015.

[5] Wu, P., Hamada, J. I. ,Yamanaka, M. D., Matsumoto, J. dan Hara, M., The Impact of Orographically-Induced Gravity Waves on the Diurnal Cycle of Rainfall over Southeast Kalimantan Island, Atmospheric and Oceanic Science Letters, 2(1), pp. 35-39, 2015.

[6] Mori, S., Hamada, J.I., Tauhid, Y.I. dan Yamanaka, M.D.,Diurnal Land-Sea Rainfall Peak Migration over Sumatera Island, Indonesian Maritime Continent, Observed by TRMM Satellite and Intensive Rawinsonde Soundings, Monthly Weather Review,132, pp. 2021-2039, 2004.

[7] Hara, M., Yoshikane, T., Takahashi, H. G., Kimura, F., Noda, A. dan Tokioka, T., Assesment of The Diurnal Cycle of Precipitation Over the Maritime Continent Simulated by a $20 \mathrm{Km}$ Mesh GCM using TRMM PR data, Journal Of The Meteorological Society of Japan, 87A, pp. 413424, 2009.

[8] Wu, P., Hamada, J.-I., Mori, S., Tauhid, Y. I., Yamanaka, M. D. dan Kimura, F., , Diurnal variation of precipitable water over amountainous area of Sumatera Island, Journal of Applied Meteorology, 42, pp. 1107$1115,2003$. 
[9] Love, B. S., Matthews, A.J. dan Lister, G.M.S., The diurnal cycle of precipitation over the Maritime Continent in a high-resolution atmospheric model, Quarterly Journal of the Royal Meteorological Society, 137, pp.934947. 2011.

[10] Azka, M.A., Sugianto, P.A., Silitonga, A.K. dan Nugraheni, I.R., Uji akurasi produk estimasi curah hujan satelit GPM IMERG di Surabaya, Indonesia, Jurnal Sains dan Modifikasi Cuaca, 19(2), pp. 83-88,2018.

[11] Sharifi, E., Steinacker, R., dan Saghafian, B., Assessment of GPM-IMERG and Other Precipitation Products against Gauge Data under Different Topographic and Climatic Conditions in Iran. Preliminary Results. Remote Sensing, 8(2), 135,2016.

[12] Zhang, W., Huang, A., Zhou, Y. et al. Diurnal cycle of precipitation over Fujian Province during the pre-summer rainy season in southern China. Theor. Appl. Climatol. 130, 993-1006, 2017.

[13] Dunkerley, D., Rain Event Properties In Nature And In Rainfall Simulation Experiments: A Comparative Review With Recommendations For Increasingly Systematic Study And Reporting, Hydrol. Process, 22, pp. 44154435,2008.

[14] Hermawan, E., 2010, Pengelompokkan Pola Curah Hujan yang terjadi di beberapa Kawasan P. Sumatera Berbasis Hasil Analisis Teknik Spektral, Jurnal meteorologi dan geofisika, 11(2), pp.75-85, 2010.
[15] Yeo, J. X., Lee, Y. H. dan Ong, J. T., Rain Attenuation Prediction model for satellite Communications in Tropical Regions, IEEE Transactions on Antennas and propagation, 52, pp. 5775-5781, 2014.

[16] Huang, W.R dan Chan, J.C.L., Maintenance mechanism for the the early morning maximum summer rainfall over southest China, Quarterly Journal of the Royal Meteorological Society, 137, pp 959-968, 2011.

[17] Wu, P., Hara, M., Hamada, J. dan Yamanaka, M.D., Why A Large Amount Of Rain Falls Over the Sea in the Vicinity Of Western Sumatera Island During Nighttime, Sola, 4, pp. 125$128,2009$.

[18] Roe, G.H., Montgomery, D.R. dan Hallet, B., Orographic Precipitation and the Relief of Mountain Ranges, Journal of Geophysical Research,108(B6-2315), pp.1-12,2003.

[19] S, O, Kirstetter, P.-E., Evaluation of diurnal variation of GPM IMERG derived summer precipitation over the contiguous US using MRMS data. Q J R Meteorol Soc. 144, 270281,2018.

[20] Tan, J., Huffman, G. J., Bolvin, D. T. dan Nelkin, E. J. Diurnal cycle of IMERG V06 precipitation. Geophysical Research Letters, 46(22), 1358413592

[21] Tang, S., Li, R., He, J., Wang, H., Fan, X., Yao, S., Comparative Evaluation of the GPM IMERG Early, Late, and Final Hourly Precipitation Products Using the CMPA Data over Sichuan Basin of China. Water, 12, 554, 2020. 